\title{
オリフィス自由噴流の混合・拡散特性の改善・制御*1 Jet Diffusion Enhancement and Control of Orifice Free Jet
}

\author{
社河内 敏彦*2 ·鬼頭 みずき*2・佐藤 光太郎*3・辻 本 公 一*2·安 藤 俊 剛*2 \\ Toshihiko Shakouchi, Mizuki Kito, Kotaro Sato, Koichi Tsujimoto and Toshitake Ando
}

Key Words : Turbulent Flows, Orifice Jet, Orifice Nozzle, Jet Oscillation, Flow Control, Flow Visualization

\begin{abstract}
Mixing and spreading characteristics of an orifice free jet are investigated changing the orifice plate thickness $t / d_{\mathrm{o}}$, where $d_{\mathrm{o}}$ is the nozzle exit diameter, ranged from 0.01 to 1.5. Schlieren images show high mixing and spreading performances at $t / d_{\mathrm{o}}=0.5$ and Reynolds number $R e=1.5 \times 10^{4}$ because at the $t / d_{\mathrm{o}}=0.5$ the jet fluctuates by the separated flow from the inner edge of orifice alternates attachment and detachment to the outer edge. Hot-wire anemometry measurements are also performed to investigate the mean and fluctuating velocity profiles. It is found that the jet potential core length is insensitive to $R e$ at $R e>7.0 \times 10^{3}$, but significantly influenced by the orifice plate thickness. The potential core length for $t / d_{\mathrm{o}}=0.5$ is the shortest reflecting the fluctuation at the nozzle exit.
\end{abstract}

\section{記 号の説明}

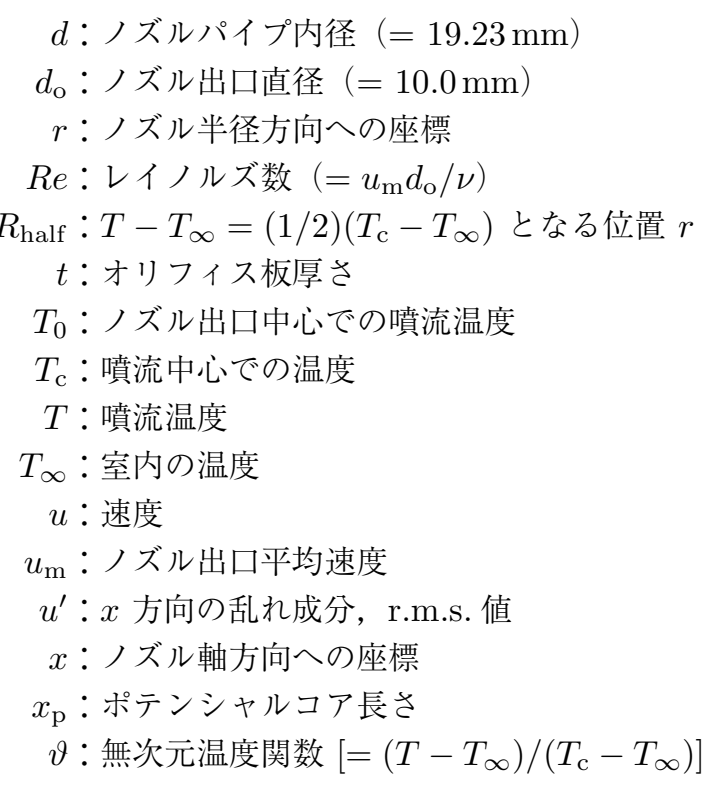

1. は じめ に

噴流の混合・拡散特性を改善・向上させることは工学的・ 工業的に重要であり，フラップ1) や音波2)を用いて強制振 動を与えるなどの能動制御や，ノズル出口にフィン3) や共 鳴室 ${ }^{4)}$ を設置し混合・拡散特性を向上させるなどの受動制 御の研究が盛んに行われている。著者らは先に, オリフィ スノズルのノズル板厚さ (以後，オリフィス板厚さと呼ぶ） を変化させ流れを振動させることができるのを示した5).す

\footnotetext{
*1 (C) 2009 日本航空宇宙学会

平成 20 年 11 月 21 日原稿受理

*2 三重大学大学院工学研究科機械工学専攻

*3 工学院大学グローバルエンジニアリング学部機械創造工学科
}

なわち，第 1 図 (a) に示すように通常のオリフィスノズル の流れはノズルエッジではく離し縮流を生じるが，ノズル 板厚さがかなり大きくなると（第 1 図 (c)）ノズルエッジで はく離した流れがノズル板内壁との間に環状の渦領域を形 成しながら内壁に再付着して流出する。第 1 図には，流れ が軸対称なため, 中心断面の半径方向に半分の領域のみの 流れの概略が示されている。これら（第 1 図 (a)，(c)）の 間にあるノズル板厚さではノズルエッジからはく離した流 れがノズル内壁との間に渦領域を形成し，ノズル出口端に 再付着したりあるいはしなかったりする状況が生起し噴流 に振動現象が生じる（第 1 図 (b)).

著者らは先に，上記の振動現象をトレーサー法による水 噴流の可視化観察とノズル出口中心での空気噴流の速度分 布, 速度变動の周波数解析によって明らかにした。しかし, トレーサー法による高レイノルズ数での噴流の可視化・観 察やオリフィス板厚さと振動現象, 混合・拡散特性に対す るレイノルズ数の影響を明らかにすることはその性質上困 難であった。

本研究では, シュリーレン法を用いて, 高温 $\left(60^{\circ} \mathrm{C}\right)$, 高 レイノルズ数での噴流の可視化・観察を行い, 噴流の振動 現象による混合・拡散特性を検討するとともに，オリフィ ス板厚さと振動現象, 混合・拡散特性に対するレイノルズ 数の影響を，熱線流速計による速度分布の測定から検討す る.さらに，噴流の温度分布と速度分布との関係を明らか にする。

\section{2. 実 験 手 順}

2.1 ノズル形状と座標系第 2 図に，ノズル形状と座 標系を示す.ノズル出口直径, パイプ直径, パイプの肉 厚，パイプ直管部長さはすべてのノズルで同一で，それ ぞれ $d_{\mathrm{o}}=10.0 \mathrm{~mm}, d=19.23 \mathrm{~mm}, t_{\mathrm{p}}=1.5 \mathrm{~mm}$, 
$L=500 \mathrm{~mm}\left(L / d_{\mathrm{o}}=50\right)$ である.ノズルは真ちゅう 製で，オリフィスノズルの絞り面積比（ノズル出口断面積/ 元のパイプ断面積）は一般的なオリフィスノズルの 0.27 と した。また，比較のため， $d_{\mathrm{o}}=10.0 \mathrm{~mm}, t_{\mathrm{p}}=1.0 \mathrm{~mm}$, $L=500 \mathrm{~mm}$ のパイプノズルも使用した.オリフィス板厚 さ $t / d_{\mathrm{o}}$ を $0.01 \sim 1.5$ と変化させ, それがオリフィス自由噴 流に及ぼす影響を検討した。ここで， $t / d_{\mathrm{O}} \leqq 0.1$ は一般的 な薄刃オリフィスである。

座標系はノズル出口中心を原点 $O$ とし, ノズルの中心 下流方向を $x$ 座標, ノズル半径方向を $r$ 座標とした.

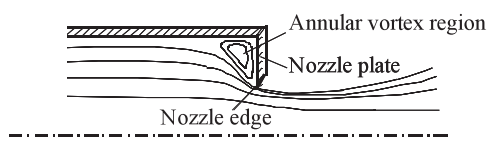

(a) Conventional orifice nozzle

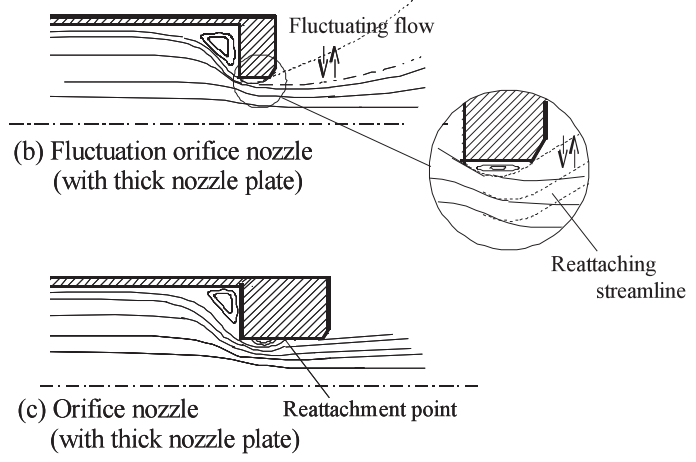

第 1 図 フローパターン

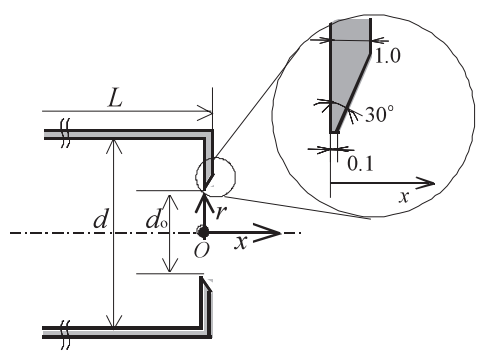

(a) Conventional orifice nozzle

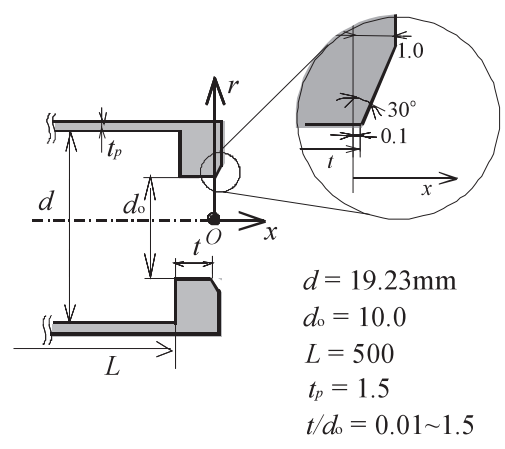

(b) Orifice nozzle with thick nozzle plate

第 2 図ノズル形状
2.2 測定装置 高レイノルズ数での噴流の拡散を明ら かにするために，ノズル出口中心で $60 \sim 65^{\circ} \mathrm{C}$ の（室温 $+40^{\circ} \mathrm{C}$ 前後) 高温空気噴流を静止大気中に噴出させ，シュ リーレン光学系 (カトウ光研, システムシュリーレン SS150 型）と高速ビデオカメラ（撮影速度：1000 frame/sec）に より流れの様子を撮影・記録した。ここで，噴流の温度は 周りより高いが, 浮力の影響は無視できる.

高温噴流の温度分布は, 熱電対 $(\mathrm{Cu}-\mathrm{Co})$ レーキを用い

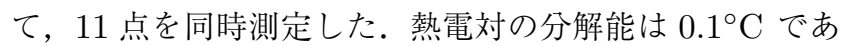
る. 測定は, $0.5 \mathrm{~Hz}$ で 1 分間取り込み, その平均（誤差： $\pm 0.3^{\circ} \mathrm{C}$ 以内）を用いた。

非加熱噴流 (室温) の平均および変動速度（乱れ強さ）分 布は, 定温度形熱線流速計・I 形プローブ (熱線：直径 $5 \mu \mathrm{m}$ のタングステン線, プロング間隔： $2.0 \mathrm{~mm}$, センサ長さ : $0.8 \mathrm{~mm}$ ) を使って測定した.

\section{3. ノズル出口速度分布}

第 3 図に $R e=1.5 \times 10^{4}$ でのパイプノズルおよびオリ フィス板厚さ $t / d_{\mathrm{o}}=0.01,0.5,1.0$ のオリフィスノズルの, ノズル出口 $\left(x / d_{\mathrm{o}}=0.2\right)$ での速度分布 $u / u_{\mathrm{m}}$ (図中, 左 半分）と乱強さ分布 $u^{\prime} / u_{\mathrm{m}}$ (図中, 右半分) を示す. 分 布形は軸対称であったのでそれぞれ半径方向半分の領域の みを示す。なお，速度の測定誤差は，その最大值に対し約 $1.5 \%$ であった.

パイプノズルでは， $L / d_{\mathrm{o}}=50$ と管長が十分長いため, 発達した管内乱流速度分布形を示し, それは $1 / 7$ 乗則でよ く表される. 一方, $t / d_{\mathrm{o}}=0.01$ の場合, 噴流外縁で最大速 度を有する分布形になりノズル出口 $\left(x / d_{\mathrm{o}}=0.2\right)$ で, 既 にかなり噴流幅が小さくなる，この現象は縮流と呼ばれ，一 般的にオリフィス噴流に生じることが知られている. なお, $t / d_{\mathrm{o}}=0.1$ の場合も縮流がみられ同様の分布形となった.

$t / d_{\mathrm{o}}$ が増加すると噴流外縁での速度が減少し噴流幅が増 加する. $t / d_{\mathrm{o}}=1.5$ では前記したようにオリフィスのノズ ルエッジではく離した流れがノズル板内壁との間に環状の 渦領域を形成しながら内壁に再付着して流れるのでその後 境界層がある程度発達するのが分かる。

乱れ強さは，いずれの場合も速度勾配が最も大きな噴流

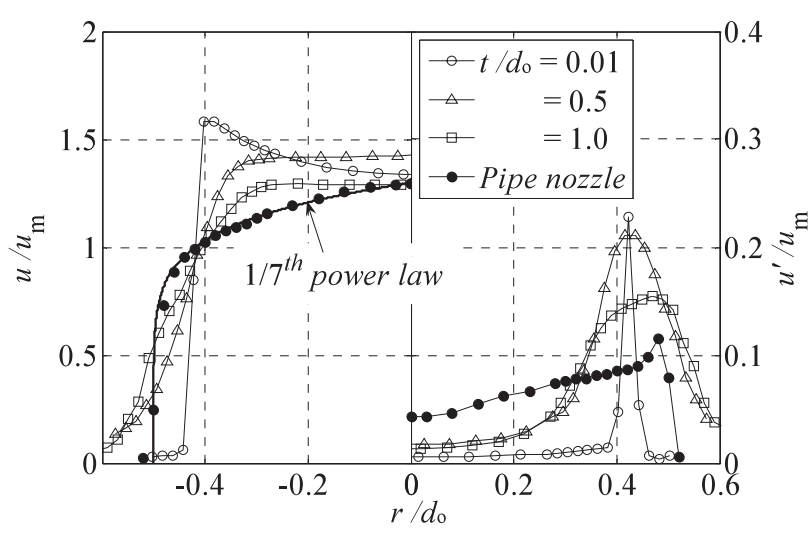

第 3 図ノズル特性 
外縁で最大となり, 噴流中心で最小となる. $t / d_{\mathrm{o}}=0.01$ での噴流外縁での乱れ強さが速度勾配に起因するのに対し, $t / d_{\mathrm{o}}=0.5$ でのそれは前記したように主に噴流に振動が生 起することによると考えられる。 また， $t / d_{\mathrm{O}}=1.5$ の乱れ 分布形では，噴流外縁である程度一定の乱れがみられ，パ イプ噴流の分布形に近づく.

なお，噴流中心付近での乱れ強さは，パイプ噴流で最も 大きく, $t$ の減少とともに小さくなる。 また, 乱れ強さが 最大となる位置は, $t$ の増加とともに噴流外縁へ移動する.

\section{4. 流れの可視化・観察}

4.1 シュリーレン画像 ノズル出ロレイノルズ数は高 温噴流の動粘性係数を用いて, $R e=1.5 \times 10^{4}=$ 一定と し，噴流の振動現象による混合・拡散特性を明らかにする。

第 4 図に瞬時のシュリーレン画像を示す. 図中の白線は, $T-T_{\infty}=(1 / 2)\left(T_{\mathrm{c}}-T_{\infty}\right)$ となる位置, すなわち温度 分布の半值幅の位置 $R_{\text {half }}$ を示す. $t / d_{\mathrm{o}}=0.5$ の場合, $t / d_{\mathrm{o}}=0.01,1.0$ ではみられない振動現象が生じ，噴流の 拡散・混合特性は他のノズルよりも著しく向上する。例え ば $t / d_{\mathrm{o}}=0.5$ の $x / d_{\mathrm{o}}=3,7$ での $R_{\text {half }}$ は $t / d_{\mathrm{o}}=0.01$ の場合のそれぞれ約 $1.3,1.6$ 倍, $t / d_{\mathrm{o}}=1.0$ の場合の 1.4 , 1.5 倍となる。

第 5 図に, 一例として異なる時刻での $t / d_{\mathrm{o}}=0.5$ のシュ

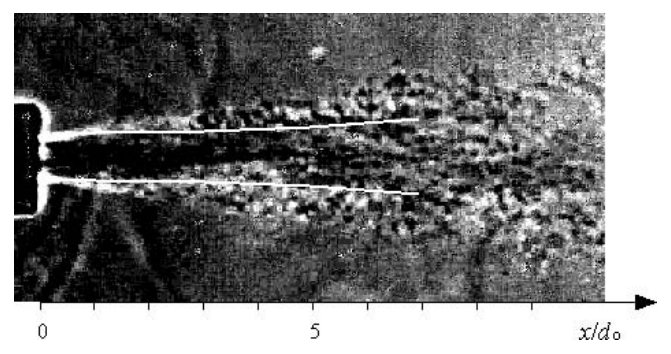

(a) $t / d_{\mathrm{o}}=0.01$

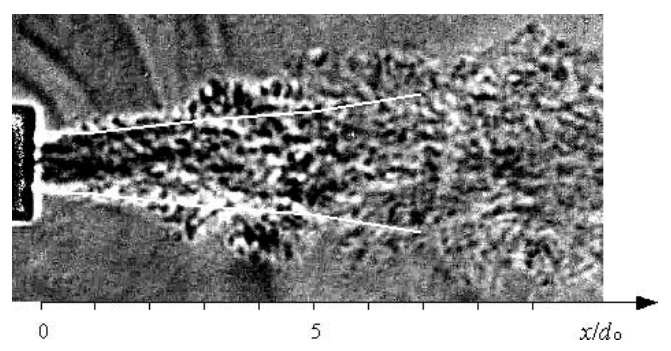

(b) $t / d_{\mathrm{o}}=0.5$

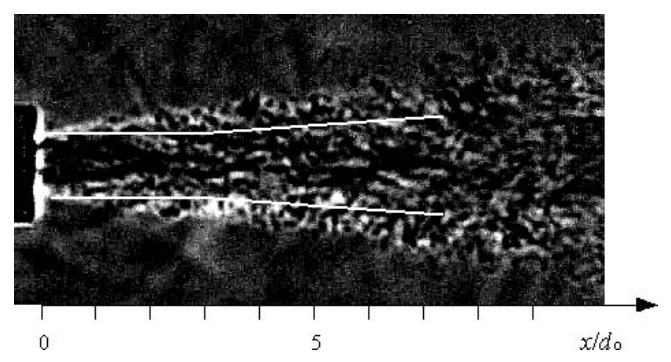

(c) $t / d_{\mathrm{o}}=1.0$

第 4 図 シュリーレン画像 $\left(R e=1.5 \times 10^{4}\right)$
リーレン画像を示す．噴流が大きく振動している様子が分 かる。これは, 前記したように, ノズルエッジからはく離し た流れがノズル出口端に再付着したりしなかったりするこ とにより，振動現象が生じると考えられる。画像で確認さ れた振動現象に周期性はなく, 時々旋回噴流の上うな挙動 を示した。ノズルエッジからはく離した流れがノズル出口 に再付着することで, 半径方向への速度が増加し, 半径方 向への拡散性が高められ, 噴流内の乱れが著しく増加する.

4.2 中心線上の温度分布 第 6 図に室温の变動を考慮し た中心線上の無次元温度分布 $\left(T_{\mathrm{c}}-T_{\infty}\right) /\left(T_{\mathrm{o}}-T_{\infty}\right)$ を示す. $t / d_{\mathrm{o}}=0.5$ の場合, 先に示した可視化画像から明らかなよ うに，噴流の半径方向への拡散性が優れている。したがっ

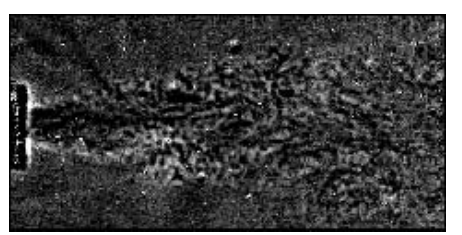

(a) $0.072 \mathrm{sec}$

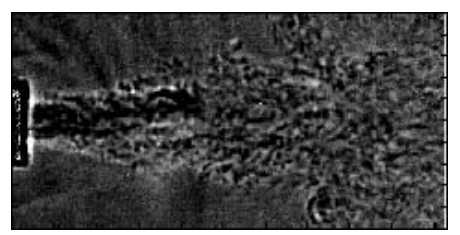

(b) $0.076 \mathrm{sec}$

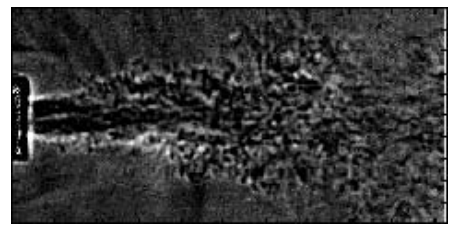

(c) $0.080 \mathrm{sec}$

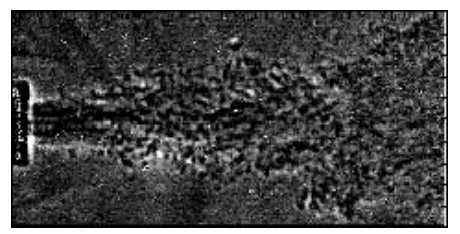

(d) $0.084 \mathrm{sec}$

第 5 図 シュリーレン画像 $\left(t / d_{\mathrm{o}}=0.5\right)$

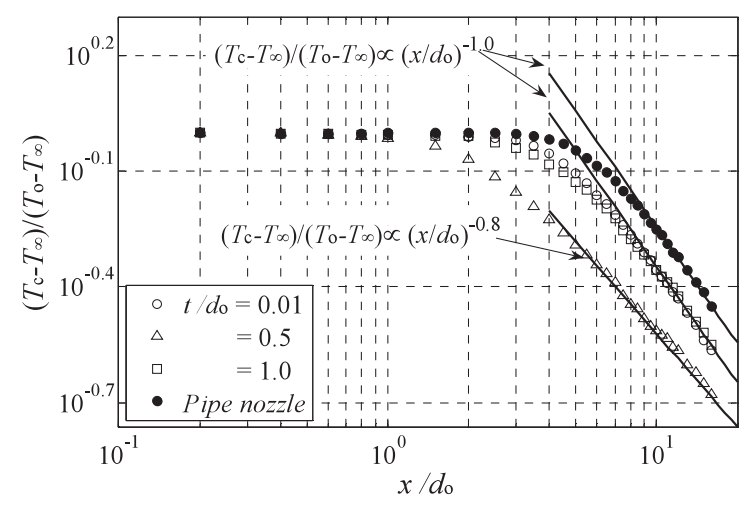

第 6 図 中心線上の温度分布 
て, $t / d_{\mathrm{o}}=0.5$ の場合, 中心線上の温度は他の噴流の場合 よりも早く減衰し始める。 なお， $t / d_{0}=0.01$ と 1.0 の中心 線温度分布は，ほぼ一致する。パイプ拉よび $t / d_{\mathrm{o}}=0.01$, 1.0 のオリフィス噴流の中心線温度は, 次式で表される.

$$
\left(T_{\mathrm{c}}-T_{\infty}\right) /\left(T_{\mathrm{o}}-T_{\infty}\right)=\left(x / d_{\mathrm{o}}\right)^{b}
$$

ここで, $b$ は実験定数で $t / d_{\mathrm{o}}=0.01,0.5,1.0$, パイプ ノズルの場合それぞれ, $b=-1.0,-0.8,-1.0,-1.0$ と なる。

$t / d_{\mathrm{o}}=0.5$ の場合, 中心線上の噴流温度は他の噴流に比 ベてやや緩やかに減衰する。温度場のポテンシャルコア長 さを，速度場の場合と同様にノズル出口温度の $95 \%$ となる 位置までとすると，ポテンシャルコア長さは， $t / d_{\mathrm{o}}=0.01$, $0.5,1.0$, パイプノズルの場合それぞれ, $x / d_{\mathrm{o}}=4.59,2.2$, 3.41，4.34 となる。このことから, 温度場のポテンシャル コア長さは, パイプ價流を除いて, 速度場のそれよりも約 $30 \%$ 短い。 これは，過去の多くの実験結果6-8) と一致する. Corrsin と Uberoi ${ }^{7}$ ) は温度変動が速度変動と異なり, ある 方向へと歪む（歪度 $\neq 00)$ ことを見いだし，それと渦の発 生を関連付けている. 半径方向への噴流の拡散は正の速度 変動によって生じ, それは大規模渦によって誘導されると 考えられる。一方, 温度変動は大規模渦が通過したことに よって生じ，低温の周囲流体を巻き込むため, 負の変動を もつ。したがって, 温度減衰は速度減衰よりも早く生じ, 温 度場のポテンシャルコア長さは速度場のそれよりも短い。

4.3 半径方向の温度分布 第 7 図に, 各断面での噴流 温度 $\vartheta$ と速度 $u / u_{\max }$ の分布形比較を示す. $t / d_{\mathrm{o}}=0.01$ の場合（通常のオリフィス噴流）, 縮流が生じ, 噴流直径 はノズル出口直後で，ノズル出口直径より小さくなるため, 噴流温度が室温と一致する半径方向位置は噴流中心に近づ $<. t / d_{\mathrm{o}}=0.5$ の場合，中心温度分布でみられたように， $x / d_{\circ}>1.0$ で，噴流は半径方向に広がるが，温度の拡散は 速度のそれより大きな分布形となる。ささらに $t / d_{0}$ が増加 すると, 速度分布と同様に温度分布は $t / d_{\mathrm{O}}=0.5$ の場合よ りもその広がりが小さくなる。

いま, 噴流中心での速度, 温度は近似的に $x^{-1} に$ 比例す ると考えると, 無次元温度分布は次式で表される ${ }^{9}$.

$$
\vartheta=\frac{T-T_{\infty}}{T_{c}-T_{\infty}}=\left(u / u_{\max }\right)^{\delta}
$$

Taylor の理論解では $\delta=1 / 2$ であり, 各噴流の断面速 度分布をもとに得た理論解を図中 $\left(x / d_{\mathrm{o}} \geqq 3.0\right)$ 実線で示 す.いずれの場合も, 実験結果と理論結果はほぼ一致する。 $t / d_{\mathrm{o}}=0.5$ の場合, 周囲流体との混合領域の発達が早いた め, $x / d_{\mathrm{o}}=3.0$ においても, Taylor の理論解でよく表さ れる。

第 8 図に, $\vartheta=1 / 2$ となる半径方向の位置 $R_{\text {half }}$ をノズル 出口直径 $d_{\mathrm{O}}$ で無次元化し白抜きの記号で示す。また, 半值 幅 $b_{1 / 2} / d_{\mathrm{o}}$ も併せて黒塗りの記号で記す. 温度分布の拡散 の様子は, 速度分布の広がり (半值幅) と同様の傾向を示す. $R_{\text {half }}$ は，ノズル出口近く $\left(x / d_{\mathrm{o}} \leqq 1.0\right)$ では，オリフィ

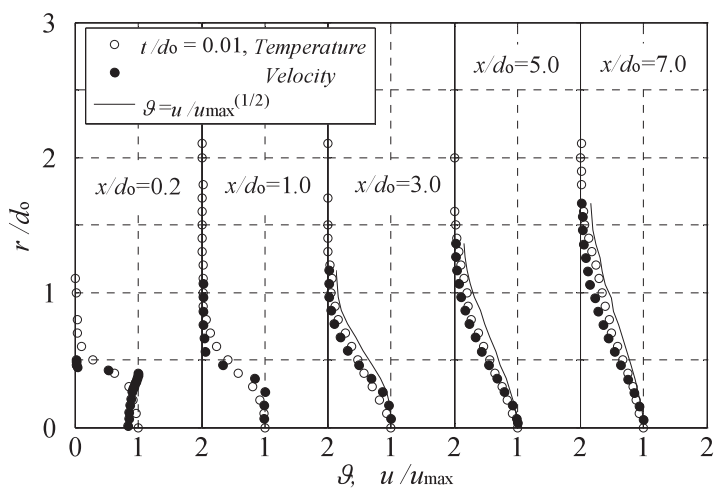

(a) $t / d_{\mathrm{o}}=0.01$

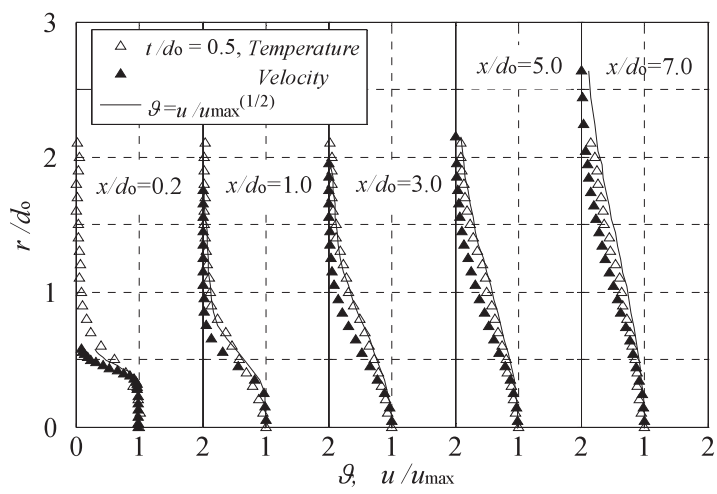

(b) $t / d_{\mathrm{o}}=0.5$

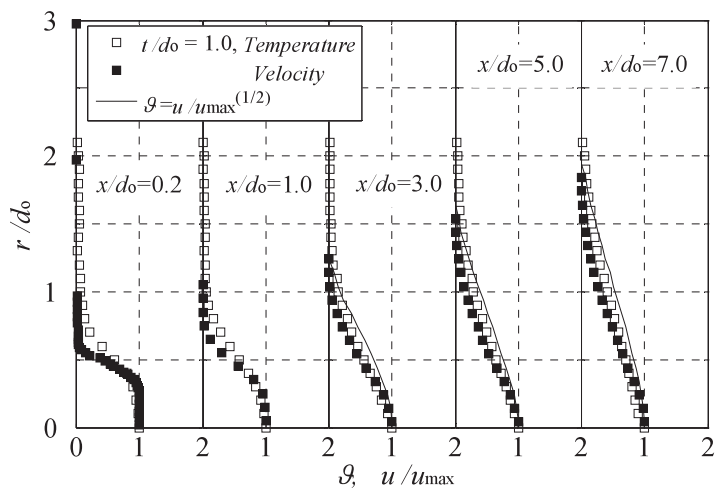

(c) $t / d_{\mathrm{o}}=1.0$

第 7 図 温度分布と速度分布の比較

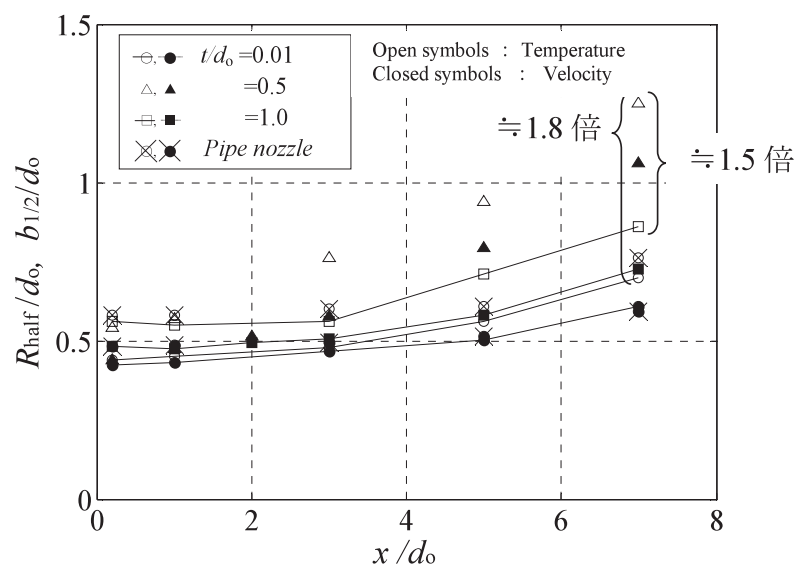

第 8 図 温度と速度の半值幅 
ス板厚さの影響はあまりみられない. しかし $x / d_{\mathrm{o}}>1.0$ で，オリフィス板厚さの影響がみられ， $t / d_{\mathrm{o}}=0.5$ の場合, 半径方向に大きく広がる. 噴流は, 下流では一定の割合で

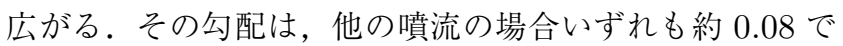
あるのに対し， $t / d_{\mathrm{o}}=0.5$ では約 0.12 である。したがっ て $t / d_{\mathrm{o}}=0.5$ の場合, 下流で噴流の広がる割合は大きい. $t / d_{\mathrm{o}}=0.5$ の場合, 下流 $x / d_{\mathrm{o}}=7.0$ での温度分布の広が りは, $t / d_{\mathrm{o}}=0.01$ の場合の約 1.8 倍, $t / d_{\mathrm{o}}=1.0$ の場合 の約 1.5 倍である.

また，温度と噴流の半值幅の比 $R_{\mathrm{half}} / b_{1 / 2}$ の平均は $0<x / d_{\mathrm{o}} \leqq 7.0$ で約 1.2 である.これは Drobniak ら のコンターノズルの結果と良い一致を示し，温度拡散の方 が速度拡散よりもやや大きい分布形となることが分かる。

\section{5. レイノルズ数の影響}

5.1 中心線上の速度分布・乱強さ分布 第 9,10 図に, オリフィス板厚さ $t / d_{\mathrm{o}}=0.01,0.5$ のノズルにおける中心 線上の平均速度 $u_{\mathrm{c}} / u_{\mathrm{m}}$ と乱強さ分布 $u_{\mathrm{c}}^{\prime} / u_{\mathrm{m}}$ を示す. 速度 の測定誤差は，その最大值に対して $R e=(0.30 \sim 2.5) \times 10^{4}$ でそれぞれ約 $3 \sim 1.5 \%$ である。平均速度分布は，高 $R e$ 数 $R e=(0.70 \sim 2.5) \times 10^{4}$ では, 安定した乱流状態となり, いずれの場合もほぼ一致する。 $t / d_{\mathrm{o}}=0.01$ の場合（第 9 図), ノズル出口で縮流が生じるため, 中心線速度がノズル 出口より増加する。 その後, 速度が変わらないポテンシャル コア領域を形成し，遷移領域を経て減衰する。中心線流速 度分布 $u_{\mathrm{c}} / u_{\mathrm{m}}$ は, 発達領域ではすべて $u_{\mathrm{c}} / u_{\mathrm{m}}=\left(x / d_{\mathrm{o}}\right)^{a}$ で表される $\left(a\right.$ : 実験定数). $R e=3.0 \times 10^{3}$ の場合, 減衰 の様子は異なるが, 高 $R e$ では $a \fallingdotseq-1.0$ で表される. 乱 れ強さ分布は $R e=(1.5 \sim 2.5) \times 10^{4}$ の場合，ほぼ一致し ピークを一つもつが, $R e=(3.0 \sim 7.0) \times 10^{3}$ の場合, 二 つのピークをもつ分布形となる。この二つのピークをもつ 分布は，低 $R e$ 数のオリフィス噴流の場合に観測され，大 規模渦構造の生成に関係すると考えられる ${ }^{10)}$.

乱強さ分布（第 10 図）は, 低 $R e$ 数の $R e=3.0 \times 10^{3}$ の場合, 二つのピークをもつ. 乱れの増減は, 大規模渦構 造生成の影響と考えられる. $R e=(0.7 \sim 2.5) \times 10^{4}$ の場 合, 実験定数は $a \fallingdotseq-0.88$ であった。 また，さらに $t / d_{\mathrm{o}}$ が増加すると, 速度分布形は $R e=(0.3 \sim 2.5) \times 10^{4}$ でほ ぼ一致し，実験定数は $a \fallingdotseq-0.92$ であった.

このことから，4.2 項で示した温度分布の減衰の様子と 速度分布のそれは同様の傾向を示し, 実験定数 $a$ は $b$ とほ ほ一致し， $t / d_{\mathrm{o}}=0.5$ の場合，中心線上の減衰は他の噴流 に比べて緩やかである。

5.2 ポテンシャルコア長さ 前記したように, ノズル近

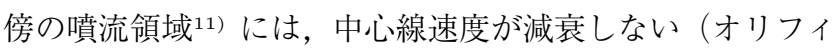
又噴流の場合は, 縮流の結果, 速度が増加した後に）ポテ ンシャルコア領域が存在する。その周りに噴流と周囲流体 とが混合する混合領域があり，混合領域が発達するに従っ て，ポテンシャルコア領域は減少し，やがて消滅する。し たがって, 噴流の混合・拡散の促進には, より早くポテン シャルコア領域を消滅させることが望ましい。なお，ポテ

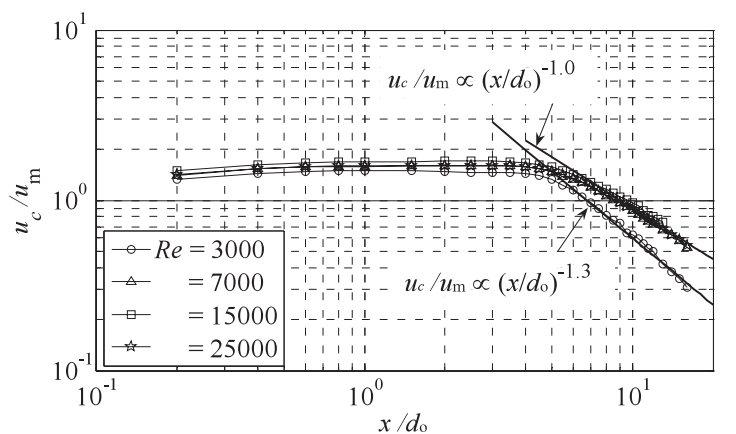

(a) 速度分布

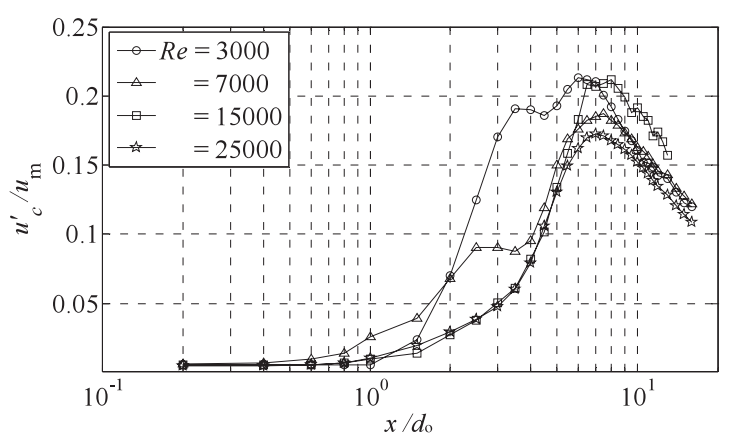

(b) 乱れ強さ分布

第 9 図 中心線速度・乱れ強さ分布 $\left(t / d_{\mathrm{o}}=0.01\right)$

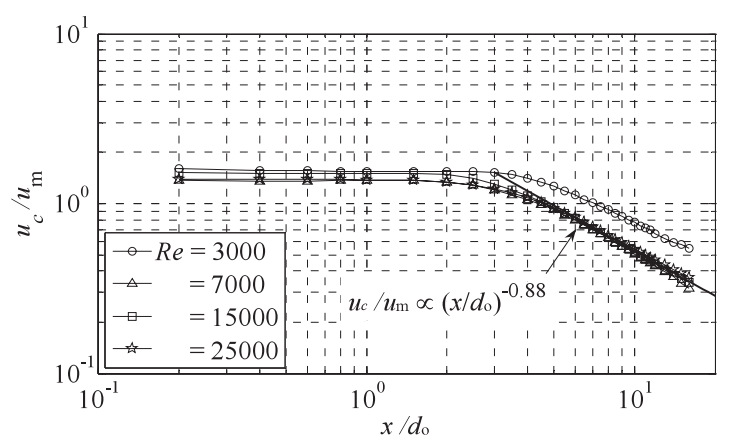

(a) 速度分布

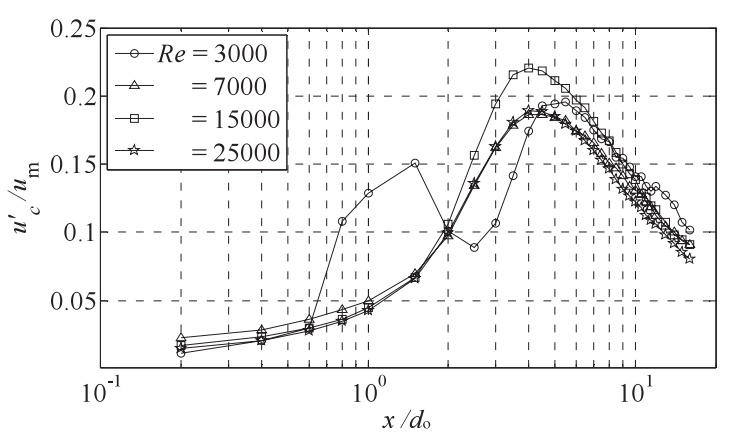

(b) 乱れ強さ分布

第 10 図 中心線速度・乱れ強さ分布 $\left(t / d_{\mathrm{o}}=0.5\right)$

ンシャルコア長さ $x_{\mathrm{p}}$ は, 中心線速度がノズル出口からノ ズル出口速度の $95 \%$ に減衰する位置までとした.

第 11 図に $R e=(0.30 \sim 2.5) \times 10^{4}$ でのポテンシャルコ ア長さ $x_{\mathrm{p}}$ に対するオリフイス板厚さ $t / d_{\mathrm{o}}$ の影響を示す. $x_{\mathrm{p}}$ は $R e=(0.70 \sim 2.5) \times 10^{4}$ では $R e$ 数に依存せず，オリ フィス板厚さ $t / d_{\mathrm{o}}=0.5$ で最小となる. $0.5 \leqq t / d_{\mathrm{o}} \leqq 1.5$, 


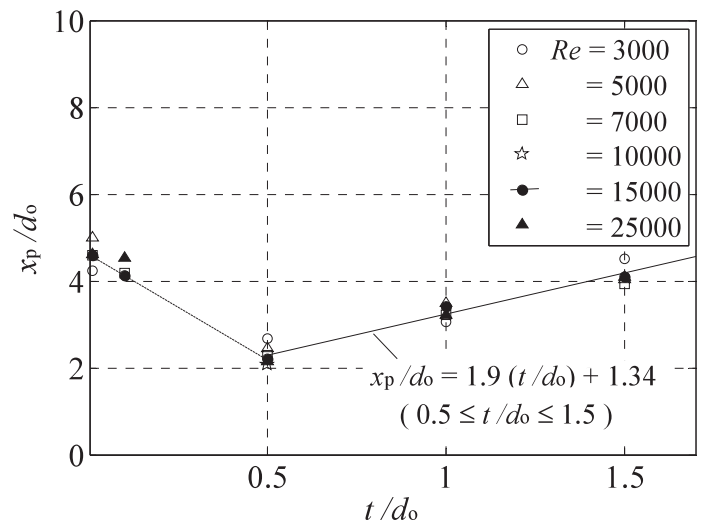

第 11 図 ポテンシャルコア長さ

$R e>0.70 \times 10^{4}$ でのポテンシャルコア長さは, 次式で表 される。

$$
x_{\mathrm{p}} / d_{\mathrm{o}}=1.9\left(t / d_{\mathrm{o}}\right)+1.34
$$

なお，パイプ噴流 $\left(t / d_{\mathrm{o}}=\infty\right)$ の場合, 本実験範囲内で はRe 数に依存せず, $x_{\mathrm{p}} / d_{\mathrm{o}} \fallingdotseq 4.4$ であった。したがって, $t / d_{\mathrm{o}}>1.5$ で, $x_{\mathrm{p}} / d_{\mathrm{o}} \fallingdotseq 4.4$ となると考えられる.

\section{6. 結論}

オリフィス板厚さと振動現象・拡散に打けるレイノルズ 数 $R e$ の影響と, 噴流の可視化観察より明らかにした。主 な結果を次に示す.

1) $R e=1.5 \times 10^{4}$ での噴流のシュリーレン可視化画像 から, $t / d_{\mathrm{o}}=0.5$ の場合, 噴流は振動現象を伴って, 半径 方向に大きく拡散することが確認された.

2）噴流の温度分布は, Taylor の理論解 $\vartheta=\left(u / u_{\max }\right)^{1 / 2}$ でよく表される。

3） ポテンシャルコア長さ $x_{\mathrm{p}} / d_{\mathrm{o}}$ は， $R e=(0.7 \sim 2.5)$ $\times 10^{4}$ では $R e$ 数にほとんど依存しない.また， $x_{\mathrm{p}} / d_{\mathrm{o}}$ は オリフィス板厚さが $t / d_{\mathrm{o}}=0.5$ の場合, $x_{\mathrm{p}} / d_{\mathrm{o}} \fallingdotseq 2.3$ で最
小となる。な损， $0.5 \leqq t / d_{\mathrm{o}} \leqq 1.5, R e>0.70 \times 10^{4}$ で のポテンシャルコア長さは, 次式で表される.

$$
x_{\mathrm{p}} / d_{\mathrm{o}}=1.9\left(t / d_{\mathrm{o}}\right)+1.34
$$

$t / d_{\mathrm{o}}>1.5$ では, パイプ噴流 $\left(t / d_{\mathrm{o}}=\infty\right)$ の場合と同 様, $x_{\mathrm{p}} / d_{\mathrm{o}} \fallingdotseq 4.4$ となると考えられる.

\section{参 考 文 献}

1）鈴木宏明，笠木伸英，鈴木雄二：フラップ型マイクロ電磁アクチュ エータ群による軸対称噴流の能動制御, 日本機械学会論文集 B 編, 65 (1999), pp. 3644-3651.

2) 宮城德誠，木村元昭，庄司秀夫，藤田 肇，程谷幸平：二次フィ ルム流と音波による能動的な噴流制御の研究（励起したフィルム 流によるエントレインメント量の変化), 日本機械学会論文集 B 編， 71 (2005), pp. 2870-2877.

3) 中島正弘, 李鹿 輝, 田畑隆英, 西田 雅, 野崎 勉: 柔らかい フィンをもつ円管から流出する噴流，可視化情報学会論文集，26 (2006), pp. 6-12.

4) 社河内敏彦, 安藤俊剛, 関根隆行, 松本 昌：共鳴噴流の流動と かく乱の増幅・制御，日本機械学会論文集 B 編， 66 (2000), pp. $352-358$.

5）鬼頭みずき, 社河内敏彦, Nuntadusit, C., 辻本公一, 安藤俊 剛：オリフィス自由噴流のノズル板厚さによる流動制御，日本機 械学会論文集 B 編, 74 (2008), pp. 1935-1941.

6) Drobniak, S., Elsner, J. W. and El-Kassem, E.-S. A.: The Relationship between Coherent Structures and Heat Transfer Processes in the Initial Region of a Round Jet, Exp. Fluids, 24 (1998), pp. 225-237.

7) Corrsin, S. and Uberoi, M. S.: Further Experiments on the Flow and Heat Transfer in a Heated Turbulent Air Jet, N.A.C.A., Technical Report 998, 1950.

8) Burattini, P. and Djenidi, L. : Velocity and Passive Scalar Characteristics in a Round Jet with Grids at the Nozzle Exit, Flow, Turbulence and Combustion, 72 (2004), pp. 199-218.

9) Abramovich, G. N.: The Theory of Turbulent Jets, Massachusetts Institute of Technology, Cambridge, Massachusetts, 1963 , pp. 124-125.

10）社河内敏彦, 鬼頭みずき, 坂本達治, 辻本公一, 安藤俊剛 : オリ フィス自由噴流の流動解析 (絞り面積比の影響), 日本機械学会 論文集 B 編, 74 (2008), pp. 42-48.

11）社河内敏彦：噴流工学一基礎と応用一, 森北出版, 東京, 2004, pp. $3-5$. 